\title{
Uma clareira no sertão? Saúde, nação e região na construção de Brasília (1956-1960)
}

\author{
A clearing in the sertão? Health, nation, and region in the \\ construction of Brasilia (1956-1960))

\section{Tamara Rangel} \\ Dissertação de Mestrado \\ Programa de Pós-graduação em História das Ciências e da Saúde, \\ Casa de Oswaldo Cruz /Fundação Oswaldo Cruz. Rio de Janeiro, 2007 \\ tamarangel@yahoo.com.br
}

No final do século XIX foi organizada, pelo governo, a primeira comissão de estudos ao Planalto Central, com o objetivo de demarcar a região para onde deveria ser transferida a capital do Brasil. Naquela época a Comissão Cruls observou que a região percorrida possuía as maiores qualidades possíveis para abarcar o empreendimento. Alguns anos depois, já no início do século XX, uma viagem de médicos sanitaristas à mesma região considerou-a vítima da pobreza, do isolamento e de doenças, uma imagem que inviabilizou o projeto mudancista e ficou associada ao Brasil Central desde então. Até a construção de Brasília outras comissões de estudos foram organizadas, e todas manifestaram preocupação com as condições de insalubridade do interior do país. Em 1956, no contexto do governo de Juscelino Kubitschek, no auge do desenvolvimentismo e do 'otimismo sanitário', o novo presidente decidiu, aparentemente de forma paradoxal, efetuar a mudança da capital para a região outrora demarcada pela Comissão Cruls. Qual seria o significado contido na inauguração de uma capital federal em pleno sertão do país, em uma região historicamente associada ao isolamento e às doenças endêmicas? Motivado por essa questão principal, este trabalho analisa as diferentes imagens de sertão que acompanharam as iniciativas em torno da mudança da capital e que interferiram na viabilização do projeto mudancista; o lugar do saneamento dos sertões nos projetos de governo, na primeira metade do século XX; a permanência da preocupação com o clima e a salubridade do Brasil Central, por parte das comissões organizadas nas décadas de 1940 e 1950; a participação ativa de Goiás na defesa da transferência da capital para a região do Planalto Central goiano; e uma análise sobre a importância do papel dos médicos e sanitaristas, ligados ou não ao governo, na construção de Brasília. 